\title{
Trade Credit, Bank Credit and Profits: Evidence from Indian Manufacturing Firms
}

\author{
Vikash Gautam (Corresponding author) \\ Indira Gandhi Institute of Development Research \\ Goregaon East, Mumbai, India
}

Tel: 91-222-8416-291Ｅ-mail: vikash.igidr@gmail.com

\author{
Rajendra R. Vaidya \\ Indira Gandhi Institute of Development Research \\ Goregaon East, Mumbai, India \\ Tel: 91-222-8416-525Ｅ-mail: vaidya@igidr.ac.in
}

$\begin{array}{ll}\text { Received: February 27, } 2015 & \text { Accepted: March 15, } 2015 \\ \text { doi:10.5296/ber.v5i1.7164 } & \text { URL: http://dx.doi.org/10.5296/ber.v5i1.7164 }\end{array}$

\begin{abstract}
An important question that is empirically under researched pertains to the relationship between trade credit (accounts payable and accounts receivable), bank credit and profits when there are imperfections in the credit market. Theory predicts complementarity between accounts payable and bank credit for financially constrained firms and substitutability for financially unconstrained firms. On the other hand, only those firms that are relatively unprofitable and constrained should invest in accounts receivable. We test these predictions using a sample of 3041 Indian manufacturing firms for the period 1993 to 2009. Trade credit transactions in the Indian context are different from the developed countries as the rediscounting of such transaction bills is almost negligible in India. Using an endogenous regime switching model, we show complementarity between accounts payable and bank credit in the event of finance constraint. We also show that firms which are unconstrained or firms which are constrained and relatively profitable do not offer trade credit. In fact, firms which are constrained and unprofitable do so.
\end{abstract}

Keywords: Trade credit, Bank credit, Profits, Finance constraint, Endogenous regime switching model 


\section{Introduction}

The reasons behind trade credit emerging as an important source of funds in both, developed and developing economies, in spite of it being costly compared to other sources of funds, has been an important area of research in the recent times. The literature offers several theories which rationalize this empirical regularity. ${ }^{1}$ A question that is empirically under researched pertains to the relationship between trade credit, bank credit and profits when there are imperfections in the credit market, i.e., when potential investors have inferior information about the investment returns than the firms. Credit market imperfections restrict the inflow of external finance as investors charge a premium, over and above its opportunity cost, on the funds they lend to hedge against downside lending risk. Firms which are unable to pursue their investment plans because of high premium are financially constrained. In contrast, firms which pay negligible premium are financially unconstrained.

Burkart and Ellingsen (2004), in an oft quoted paper, have developed a theoretical model that investigates the relationship between trade credit, bank credit and profits under credit market imperfections. ${ }^{2}$ For a firm which is unconstrained in the bank credit market, the desired investment expenditure $I^{*}$ can be met using bank credit $\left(L_{E}\right)$ or/and as the internal wealth $(w)$.

So, we have:

$$
I^{*} \leq L_{B}+W
$$

Equation (1) suggests that addition of trade credit received $\left(L_{5}\right.$, which would show up as accounts payable in a firm's book) to the right hand side would substitute for the bank credit or the internal wealth. However, if the firm is constrained in the bank credit market and can borrow only $\bar{L}_{E}$ then equation (1) would evolve as:

$$
I^{*}>\bar{L}_{B}+W
$$

In this setting there can be two cases: if the firm is unconstrained in the trade credit market, it would borrow $L_{s}^{*}=I^{*}-\bar{L}_{E}-w$. Alternatively, if the firm is constrained in the trade credit market, it would borrow $\bar{L}_{s}$ where $\bar{L}_{s}<L_{s}^{*}$. Thus, the firm's investment would be:

1 These theories can be broadly grouped into: inventory management theories, information asymmetry theories, risk sharing theories, discrimination theories, product quality theories, bankruptcy theories and externality theories. See Petersen and Rajan (1997) and Bougheas et al. (2009) for a summary of these theories.

2 Their model offers a host of other predictions regarding trade credit. In this paper we focus only the relationship between trade credit, bank credit and profits. 


$$
I^{*}=\min \left\{\left(L_{s}^{*}+\bar{L}_{E}+w\right) \cdot\left(\bar{L}_{5}+\bar{L}_{E}+w\right)\right\}
$$

Equation (3) suggests that accounts payable and bank credit would be compliments for firms which are constrained in the bank credit market. Biais and Golier (1997) also arrive at a similar prediction, albeit using a different line of argument. They argue that banks, which do not have private information about an investment project of a firm, use trade credit as a signaling mechanism to assess firm's creditworthiness. Therefore, bank and trade credit would appear as complements.

Burkart and Ellingsen (2004) point out that many firms offer trade credit (accounts receivable in their books) even though they are already indebted to banks and other firms. This is because accounts receivable bills can be rediscounted with banks and thus offering trade credit does not necessarily force firms to reduce investment. Accordingly, their model predicts that financially unconstrained firms, even when indebted, may offer trade credit. In such a case, even those firms that are financially constrained but highly profitable would extend trade credit.

Banks in the Indian context, in contrast, do not universally accept trade credit bills for rediscounting. The Reserve Bank of India (Indian Central Bank) delineates the several guidelines for rediscounting of such bills which indicates its concern over their genuinity and the potential negative influence they may have on the health of the financial system. ${ }^{3}$ As a consequence, the average number of inland accounts entertained for bills discounting as a percentage of total number of accounts with scheduled commercial banks is a meager $0.3 \%$ in the period 1996 to 2010 and the average volume of inland bills discounted as a percentage of outstanding credit by scheduled commercial banks is only $1.7 \%$ in the same period. ${ }^{4}$ This clearly indicates the reluctance of banks in India to rediscount accounts receivable despite the fact that trade credit along with other informal credit sources (credit from friends, relatives, etc.) dominate over bank credit (Allen et al., 2012). The Indian context, therefore, provides a natural ground to examine the relationship between trade credit, bank credit and profits when there are imperfections in the credit market and the rediscounting of trade credit bills is significantly discouraged.

If banks do not rediscount accounts receivable and there is concern over the quality of the borrower firm, there is no reason for financially unconstrained firms to offer trade credit. Firms that are financially constrained but highly profitable would also not extend trade credit as they would retain liquidity to safeguard future profitable investment opportunities. But, firms that are constrained and relatively unprofitable may still offer trade credit for at least two reasons (Petersen and Rajan, 1997; Wilner, 2000; Cunat, 2007). Firstly, offering trade credit would help such firms in maintaining their sales by reducing costly finished goods inventories. Secondly, it would insure them against future downside market risk by establishing a relationship.

\footnotetext{
${ }^{3}$ See RBI Master Circular on Credit and Advances dated July 02, 2012.

${ }^{4}$ Numbers are obtained from RBI Publications on Trends and Progress of Banking in India.
} 
A major difficulty in testing these predictions is that the finance constraints are not directly observable. Researchers have proposed different approaches to distinguish financially constrained from unconstrained firms. The first approach is to sort firms into constrained or unconstrained groups according to a univariate distribution of some variable such as maturity, size, dividend payout, etc., which is supposed to be related to their creditworthiness (e.g., Fazzari et al. 1988; Gilchrist and Himmelberg 1995). Such an approach, however, does not produce an unambiguous characterisation of firms into financially constrained and unconstrained groups. Alternatively, some researchers follow a multivariate approach which sums up several aspects of firms' structure into a single indicator (e.g., Kaplan and Zingales 1997; Hu and Schiantarelli 1998; Hovakimain and Titman 2006; Whited and Wu 2006). ${ }^{5}$ Following Hu and Schiantarelli (1998) and Hovakimain and Titman (2006) we employ the later approach to identify financially constrained firms by using an endogenous regime switching model. The endogenous regime switching model estimates a selection function which exploits information from a set of variables making finance constraints a multi-faceted phenomenon.

We use data on a sample of firms drawn from the Indian manufacturing sector in the period 1993 to 2009 for our empirical exercise. The results suggest that as the shortage of bank credit intensifies for firms, their reliance on trade credit increases. This is an intuitive finding on the complementarity between sources of funds in the event of finance constraints. On the other hand, the results also reveal that firms which are unconstrained or firms which are constrained and relatively profitable do not offer trade credit. In fact, firms which are constrained and unprofitable do so. Such an outcome is likely to be due to negligible rediscounting of trade credit bills for the firms in the sample. The result on complimentarity between accounts payable and short term bank credit confirms the prediction of Burkart and Ellingsen (2004). The result of accounts receivable and profits, on the other hand, supports the arguments of costly finished goods inventories and risk sharing as suggested by Petersen and Rajan (1997), Wilner (2000), and Cunat (2007).

The reminder of the paper is organized as follows: we discuss our empirical strategy in section 2 followed by the discussion of the data and the variables in section 3 . Section 4 presents the results from the baseline model. In section 5, we divide the sample into financially constrained and unconstrained regimes and provide our main results. Section 6 carries out the robustness checks. Finally, section 7 concludes.

\section{Empirical Strategy}

The literature has already talked about trade credit as a tool for risk sharing (Wilner 2000; Cunat 2007). An important aspect in such a context is whether firms persistently engage in

\footnotetext{
${ }^{5}$ Several researchers use information from credit rating of firms whereas several others use indicator variables which require hard data (i.e., information through business registers, qualitative information). We exclude these approaches as such information is unavailable for most of the firms in our sample.
} 
trade credit transactions or not. Ignoring persistence, when it exists, may bias the inferences. ${ }^{6}$ We employ Arellano-Bond (1991) test for serial correlation to ascertain persistence.

Presence of persistence requires dynamic panel estimation because cross-sectional and simple panel data models would bias the estimate of the lagged dependent variable due to its correlation with the fixed effects (Nickell, 1981). However, since the conditions leading to finance constraints may change over time, the unit of analysis would be firm-year and the structure of the data would essentially be cross-sectional. In such a setting, the fixed effects can be removed by mean-differencing the variables. But, the dynamic panel bias still remains. Following Nickel (1981) we know that this bias would be negative if the coefficient of lagged dependent variable is positive. Thus, in the cross-sectional setting, a positive coefficient associated with lagged dependent variable would imply that the results are valid with even greater force.

Finance constraint in firms is endogenous to their observable and unobservable characteristics. We, therefore, use endogenous regime switching model for our main empirical analysis. The model is composed of a system of three equations that are estimated simultaneously:

$$
\begin{aligned}
& S_{1 i t}=X_{i t} \beta_{1}+u_{1 i t} \\
& S_{2 i t}=X_{i t} \beta_{2}+u_{2 i t} \\
& y_{i t}^{*}=Z_{i t} \gamma+\varepsilon_{i t}
\end{aligned}
$$

Equations (4) and (5) refer to trade credit transactions in alternative financing regimes. $S$ denotes trade credit (accounts payable, accounts receivable); $i$ and $t$ indicate firm and year, respectively, and; $X$ is the set of explanatory variables including fixed firm and year effects. Equation (6) is the selection equation where $y_{i t}^{*}$ is the latent variable measuring the likelihood of firm $i$ to be in either of the regimes at time $t . Z_{\text {it }}$ is the set of the determinants of $y_{i t}^{*} . \beta_{1}, \beta_{2}$ and $\gamma$ are vectors of parameters and $u_{1 i t}, u_{2 i t}$, and $\varepsilon_{i t}$ are residuals. We assume $u_{1 i t}, u_{2 i t}$, and $\varepsilon_{i t}$ to be jointly normally distributed with mean vector 0 and

\footnotetext{
${ }^{6}$ It is not possible to track the origin and destination of each trade credit transaction due to data limitations. This restricts an in-depth analysis of risk sharing between firms.
} 
covariance matrix $\Sigma=\left[\begin{array}{ccc}\sigma_{M 1} & \sigma_{I 2} & \sigma_{I \varepsilon} \\ \sigma_{I 2} & \sigma_{22} & \sigma_{2 \varepsilon} \\ \sigma_{I \varepsilon} & \sigma_{2 \varepsilon} & I\end{array}\right]$. This assumption permits a nonzero correlation between the shocks to trade credit and the shocks to firm's characteristics. Variance of $\varepsilon_{\mathrm{it}}$ is normalised to 1 since we can estimate only $\gamma / \sigma_{\varepsilon}$, but not $\gamma$ and $\sigma_{\varepsilon}$ individually. The observed $S_{\text {it }}$ for firm $i$ at time $t$, can be defined as

$$
\begin{aligned}
& S_{i t}=S_{1 i t} \quad \text { iff } \quad y_{i t}^{*}<0 \\
& S_{i t}=S_{2 i t} \quad \text { iff } \quad y_{i t}^{*} \geq 0
\end{aligned}
$$

We can calculate the probability of a firm being in one or the other regime as:

$$
\begin{gathered}
\operatorname{Prob}\left(S_{1 i t}\right)=\operatorname{Prob}\left(Z_{i t} \gamma+\varepsilon_{i t}<0\right)=\operatorname{Prob}\left(\varepsilon_{i t}<-Z_{i t} \gamma\right)=\Phi\left(-Z_{i t} \gamma\right) \\
\operatorname{Prob}\left(S_{2 i t}\right)=\operatorname{Prob}\left(Z_{i t} \gamma+\varepsilon_{i t} \geq 0\right)=\operatorname{Prob}\left(\varepsilon_{i t} \geq-Z_{i t} \gamma\right)=1-\Phi\left(-Z_{i t} \gamma\right)
\end{gathered}
$$

here $\Phi($.$) is the cumulative distribution function. S_{\text {it }}$ is, thus, a weighted conditional density function of $u_{1 i t}$ and $u_{2 i t}$ with weights $\Phi\left(-Z_{i t} \gamma\right)$ and $\left[1-\Phi\left(-Z_{i t} \gamma\right)\right]$, respectively. For $\phi($.$) ,$ $\phi\left(u_{j i t} \mid\right)$ and $\phi\left(u_{j i t}, \sigma_{j j}\right)$ denoting normal density function, conditional density function and marginal density function, respectively, where $j=\{1,2\}$, we have:

$$
\begin{array}{r}
S_{i t}=\phi\left(u_{1 i t} \mid \varepsilon_{i t}<-Z_{i t} \gamma\right) \Phi\left(-Z_{i t} \gamma\right)+\phi\left(u_{2 i t} \mid \varepsilon_{i t} \geq-Z_{i t} \gamma\right)\left[1-\Phi\left(-Z_{i t} \gamma\right)\right] \\
=\phi\left(u_{1 i t}, \sigma_{11}\right) \Phi\left[\frac{-Z_{i t} \gamma-\frac{\sigma_{1 \varepsilon}}{\sigma_{11}} u_{1 i t}}{\sqrt{1-\frac{\sigma_{1 \varepsilon}^{2}}{\sigma_{11}}}}\right]+\phi\left(u_{2 i t}, \sigma_{22}\right)\left[1-\phi\left(\frac{-Z_{i t} \gamma-\frac{\sigma_{2 \varepsilon}}{\sigma_{22}} u_{2 i t}}{\sqrt{1-\frac{\sigma_{2 \varepsilon}^{2}}{\sigma_{22}}}}\right)\right]
\end{array}
$$

The second equality in equation (11) uses the fact that a joint density equals the product of conditional density and marginal density. For a panel of $N$ firms with $T_{i}$ observations for firm $i$, the log likelihood function is given by 


$$
L=\sum_{i=1}^{N} \sum_{t=1}^{T_{\tilde{i}}} \log \left(S_{i t}\right)
$$

The estimates of $\beta_{1}, \beta_{2}$ and $\gamma / \sigma$ can be obtained by maximising the log-likelihood function.

The endogenous regime switching model, besides allowing firms to change regime endogenously, uses a set of variables to infer finance constraints associated with each firm-observation. Thus, it provides an unequivocal characterisation of finance constraints. Interpretation of results from the endogenous regime switching model, however, needs an additional care as the coefficients in the two regimes for each of the variables are expressed in relative terms.

\section{Data and Variables}

The data used in this paper is based on major industries in the Indian manufacturing sector from 1993 to 2009. We use PROWESS, corporate data directory of the Center for Monitoring of Indian Economy (CMIE) as the major data source. It is the largest and most comprehensive database of the financials on Indian firms covering around 3300 data items and ratios per firm.

We choose firms based on the following criteria: firstly, we consider only private firms. Public sector enterprises and foreign firms are excluded as such firms are controlled by the Ministry of Industry and a foreign parent company, respectively. Secondly, to ensure that the firms are mainly into manufacturing business, we require sales of manufactured goods to contribute at least 75 per cent of the total sales for at least two-third of the sample period. Thirdly, we drop firms undergoing major restructuring. We identify such firms as those reporting unreasonable jump in manufactured sales. ${ }^{7}$ Fourthly, we exclude financially distressed firm-observations from the sample as firms in such condition are more likely to use a marginal rupee to repay creditors than for normal operation. Inclusion of distressed firms in the sample would bias the results on the relationship between trade credit, bank credit and profits. A firm is defined as distressed in a year if its profit before depreciation, interest, taxes and amortisation (PBDITA) is less than 80 percent of interest accrued in that year or PBDITA is less than interest accrued in the year and the year before. Fifthly, we require firms to have at least three years of continuous data for our econometric exercise. Finally, for variables which portray extreme values, we winsorise one percent observations at both the ends. Meeting these conditions, we get an unbalanced panel of 25186 observations from 3041

\footnotetext{
${ }^{7}$ We allow up to a ten-fold jump if the manufactured sales is up to Rs. 10 million; five-fold if the manufactured sales is between Rs. 10 million to Rs. 50 million; four-fold if the manufactured sales is between Rs. 50 million to Rs. 100 million; three-fold if the manufactured sales is between Rs. 100 million to Rs. 250 million; and two-fold if the manufactured sales is above Rs. 250 million. Results remain consistent with various other cutoffs.
} 
firms.

Among the drivers of trade credit, inventory is a key variable. ${ }^{8}$ Firms accept trade credit to build inventories of raw materials and semi-finished goods whereas they offer trade credit as a strategy to lower their finished goods inventories. Therefore, inventories should have positive relationship with accounts payable and negative relationship with accounts receivable. Firms with larger size, more collateralisable assets and more liquid assets are likely to find it easier to utilise funds from other cheaper sources as they are more reputed in the formal credit markets. Firms with higher profits are less likely to have larger accounts payable as profits constitute a cheaper source of funds. Firms with higher profits are also less likely to have larger accounts receivable as rediscounting of such transaction bills is negligible. Moreover, they are also less vulnerable to uncertain demand and hence stocks of finished goods inventories. Finally, firms' would demand for trade credit only to the extent that the requisite need for finance is not met by formal sources. Suppliers of trade credit, on the other hand, may channel finance from other sources to the borrowers who may find it difficult to tap these sources.

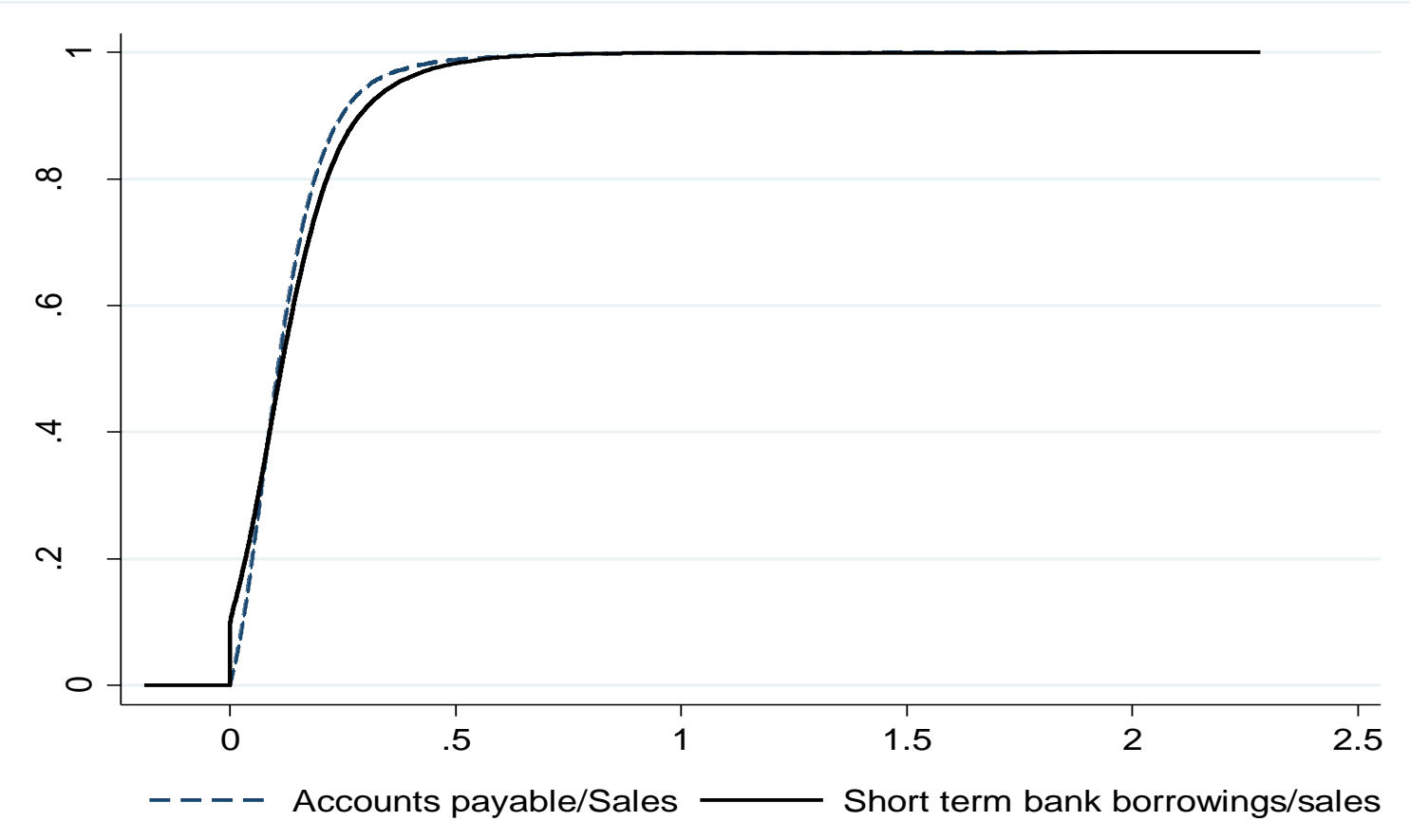

Figure 1. Stochastic Dominance Plot

The data suggests that accounts payables are almost as important source of finance as short term bank credit in terms of stochastic dominance (figure 1). This is also evident in table 1 as the mean (median) accounts payable is close to short term bank credits. This pattern is consistent with the finding of Allen et al. (2012) that credit from informal sources (trade credit and borrowings from friends, relatives, etc.) dominates over bank credit in Indian

${ }^{8}$ Variables are defined in the Appendix. 


\section{Macrothink}

Business and Economic Research

ISSN 2162-4860 2015, Vol. 5, No. 1

manufacturing firms' debt portfolio. An insightful way to assess the nature of trade credit transactions is by looking at days payable outstanding (DPO) and days sales outstanding (DSO). DPO indicates the average number of days firms defer their trade credit bills. It is computed as industry average accounts payable multiplied by number of days in a year (365) and normalised by sales. DSO indicates the average number of days firms wait for the realisation of trade credit bills. It is computed as Industry average accounts receivable multiplied by 365 and normalised by sales. These numbers are broadly comparable to numbers in other countries (Miwa and Ramseyer, 2005). Significant heterogeneity across all other variables in the table is clearly evident.

Table 1. Summary statistics

\begin{tabular}{|l|l|l|l|}
\hline Variable & Mean & Median & Standard Deviation \\
\hline Accounts payable/Sales & 0.1281 & 0.1053 & 0.1076 \\
\hline Accounts receivable/Sales & 0.1783 & 0.1511 & 0.1437 \\
\hline Days payable Outstanding & 46.6816 & 38.4486 & 38.9444 \\
\hline Days Sales Outstanding & 65.1079 & 55.2989 & 52.1036 \\
\hline Log age & 2.9245 & 2.8904 & 0.7321 \\
\hline Inventory/Sales & 0.1058 & 0.0743 & 0.1119 \\
\hline Finished goods inventory/Sales & 0.0733 & 0.0446 & 0.0998 \\
\hline Inputs and semi-finished goods inventory/Sales & 0.1041 & 0.0795 & 0.0954 \\
\hline Collateral & 0.6241 & 0.6108 & 0.2784 \\
\hline Accelerator/Sales & 0.1219 & 0.1247 & 0.2537 \\
\hline Profit/Sales & 0.1251 & 0.1074 & 0.0918 \\
\hline Dividend/Sales & 0.0064 & 0.0000 & 0.0114 \\
\hline Liquid assets/Sales & 0.0603 & 0.0254 & 0.1177 \\
\hline Short term bank credit/Sales & 0.1370 & 0.1127 & 0.1266 \\
\hline
\end{tabular}

\section{Baseline Model}

We estimate the following baseline model using the Blundell-Bond (1998) system dynamic panel-data method:

$$
\begin{aligned}
& \frac{S_{i t}}{\text { Sales }_{i t}}=\alpha_{i}+\beta_{0} \frac{S_{i t-1}}{\text { Sales }_{i t-1}}+\beta_{1} \text { Size }_{i t}+\beta_{2} \text { Collateral }_{i t}+\beta_{3} \frac{\text { Inventories }_{i t}}{\text { Sales }_{i t}}+\beta_{4} \frac{\text { Profits }_{i t}}{\text { Sales }_{i t}} \\
& +\beta_{5} \frac{\text { Liquid assets }_{\mathrm{it}}}{\text { Sales }_{\mathrm{it}}}+\beta_{6} \frac{\text { Short term bank credit }_{\mathrm{it}}}{\text { Sales }_{\mathrm{it}}}+e_{\mathrm{it}}
\end{aligned}
$$


Table 2. System dynamic panel-data estimation

\begin{tabular}{|l|l|l|l|l|}
\hline & \multicolumn{2}{|l|}{ Accounts payable/Sales } & \multicolumn{2}{l|}{ Accounts receivable/Sales } \\
\hline & 1 & 2 & 1 & 2 \\
\hline L1. Dep. Var. & $0.1514^{* * *}$ & $0.1381^{* * *}$ & $0.4241^{* * *}$ & $0.4171^{* * *}$ \\
\hline & $(36.21)$ & $(32.58)$ & $(35.25)$ & $(37.61)$ \\
\hline Inventory /sales & $0.0833^{* * *}$ & & $-0.0546^{* *}$ & \\
\hline & $(3.68)$ & & $(2.62)$ & \\
\hline Finished goods inventory /sales & & $0.0836^{* * *}$ & & $-0.0792^{* * *}$ \\
\cline { 2 - 6 } & & $(3.41)$ & & $(3.97)$ \\
\hline Input and semi-finished goods inventory /sales & & $0.2714^{* * *}$ & & $0.0722^{* *}$ \\
\cline { 2 - 6 } & & $(9.24)$ & & $(2.85)$ \\
\hline Log assets & -0.0017 & -0.0026 & -0.0025 & $-0.0043^{*}$ \\
\hline & $(0.84)$ & $(1.30)$ & $(1.29)$ & $(2.45)$ \\
\hline Collateral & $0.0225^{* *}$ & $0.0207^{* *}$ & $-0.0210^{* *}$ & $-0.0184^{* *}$ \\
\hline & $(3.15)$ & $(2.90)$ & $(3.02)$ & $(2.78)$ \\
\hline Profit/sales & $-0.1553^{* * *}$ & $-0.1605^{* * *}$ & 0.0208 & 0.0398 \\
\hline & $(7.62)$ & $(8.59)$ & $(0.96)$ & $(1.20)$ \\
\hline Liquid assets/sales & $0.1567^{* * *}$ & $0.1899^{* * *}$ & 0.0081 & 0.0042 \\
\hline & $(7.62)$ & $(10.60)$ & $(0.57)$ & $(0.32)$ \\
\hline Short term bank loan/sales & $0.1176^{* * * *}$ & $0.0768^{* * *}$ & $0.0683^{* * *}$ & $0.0825^{* * *}$ \\
\hline & $(7.29)$ & $(4.88)$ & $(3.57)$ & $(4.89)$ \\
\hline M1 (Abs. Z-statistics) & $7.7676^{* * *}$ & $9.4279^{* * *}$ & $14.0870^{* * * *}$ & $14.0420^{* * *}$ \\
\hline M2 (Abs. Z-statistics) & 1.3344 & 1.7159 & 0.9516 & 1.0521 \\
\hline Sargan (Chi2-statistics) & 0.4100 & 0.4785 & 0.4887 & 0.5425 \\
\hline
\end{tabular}

Notes: Absolute z-statistics are in parentheses. M1 and M2 are Arellano-Bond test for zero autocorrelation in first-differenced errors with the null as no autocorrelation. Sargan test is the test of over identifying restrictions distributed as chi-square under the null of instrument validity. $*, * *$, and $* * *$ indicate significance at $5 \%, 1 \%$ and $0.1 \%$, respectively.

Here, $S_{i t}$ denotes accounts payable or accounts receivable, $i$ denotes firm, $t$ denotes year, $\beta^{\prime} s$ are coefficients associated with the explanatory variables and $e_{i t}$ is white noise. Size is measured as log assets. Collateral is measured as gross fixed assets divided by total assets. Inventories include both, stock of finished as well as of input and semi-finished goods inventories. In another variant of this model we keep the two inventory variables separate. Profits is profit before depreciation, interest, taxes and amortisation. Liquid assets is sum of cash, bank balances and marketable securities. Short term bank credit is loans taken from banks for less than a year.

The results are presented in the table 2. The second and third columns report the results for accounts payables and the last two columns report the same for accounts receivable. Among the main variables of interest, the coefficient associated with short term bank credit is 
positive and significant across all the columns. On one hand, it implies complementarity between accounts payable and short term bank credit; while on the other, it implies that firms pass on some of the short term bank credit to other firms as accounts receivable. The coefficient of profits is significant only for accounts payable with a negative sign suggesting that lack of internal funds is compensated with incoming trade credit. It is important to note that the coefficients associated with lagged dependent variables are positive and significant suggesting persistence in trade credit transactions. This is also evident by looking at the test statistic for first- and second-order serial correlation (M1 and M2, respectively). M1 turns out to be significant whereas M2 is insignificant. These evidences portray the dynamics of the trade credit transactions for an average firm but they are mostly inconclusive in the context of our hypotheses. In the next section, we explore the determinants of trade credit using an endogenous regime switching model and discuss results in a greater detail.

\section{Endogenous Regime Switching Model}

Empirical specification of the trade credit equation for the endogenous regime switching model is same as equation (13). ${ }^{9}$ The variables used for describing $Z_{\text {it }}$ in selection equation (equation (6) in section 2), are- log assets, log age, dividend payout, liquid assets, sales accelerator, short term credit, long term credit, exports and group affiliation. All the variables except $\log$ assets, log age and group affiliation are normalised by sales. The rationale for these variables is as follows: firms with bigger size (log assets) command more resources than firms with smaller size. Hence, they are less likely to be financially constrained (Hovakimian and Titman, 2006). Mature firms (firms with higher log age) are well reputed and get more analyst coverage than younger firms. Hence, they are less vulnerable to financing problems (Devereux and Schiantarelli, 1990). Dividend payout is a competing use of funds against other alternatives such as investment. So, more constrained firms should choose low dividend payout (Fazzari et al., 1988). Firms with more liquid assets are more likely to be financially constrained as they hold it to safeguard profitable future investment opportunities against downside fluctuations in net worth (Fazzari and Petersen, 1993). Firms with high growth opportunities (accelerator) indicate further scope for profitable investments. If such firms are well recognised in the credit market, they are less likely to be financially constrained. However, if such firms are backed by low cash flows and collaterisable assets, they are more likely to be financially constrained (Hovakimian and Titman, 2006). Firms with high debt signal higher probability of bankruptcy during a business downturn. Therefore, they may face higher hurdles in accessing external sources of funds (Jensen and Meckling, 1976). Firms which export more are more capable of surviving and doing well. Such firms are less likely to be financially constrained (Ganesh-Kumar et al., 2001). Group firms have their internal capital market making them less likely to be financially constrained (Hoshi et al., 1991).

\footnotetext{
${ }^{9}$ We only present the results by breaking up inventories into finished goods inventories and input and semi-finished goods inventories. The results are consistent even without the break-up.
} 
Table 3. Endogenous regime switching model

Panel A. Selection Equation

\begin{tabular}{|l|l|l|}
\hline Dependent variable: regime dummy & Accounts payable/Sales & Accounts receivable/Sales \\
\hline Log assets & $-0.0579^{* * *}$ & $0.0138^{*}$ \\
\hline & $(9.46)$ & $(2.33)$ \\
\hline Log age & $0.2572^{* * *}$ & $-0.4325^{* * *}$ \\
\hline & $(9.07)$ & $(10.23)$ \\
\hline Dividend/Sales & $3.8357^{* * *}$ & $-1.8230^{* * *}$ \\
\hline & $(9.55)$ & $(4.67)$ \\
\hline Liquid assets/Sales & -0.0675 & $-0.1632^{* * *}$ \\
\hline & $(1.94)$ & $(4.82)$ \\
\hline Accelerator/Sales & $-0.6311^{* * *}$ & $0.4978^{* * *}$ \\
\hline & $(5.30)$ & $(5.11)$ \\
\hline Short term credit/Sales & $-0.2501^{* * *}$ & $0.0717^{* *}$ \\
\hline & $(9.82)$ & $(2.90)$ \\
\hline Long term credit/Sales & $-0.1872^{* * *}$ & $0.0520^{* * *}$ \\
\hline & $(6.34)$ & $(4.67)$ \\
\hline Exports/Sales & $0.8791^{* * *}$ & $-0.4648^{* * *}$ \\
\hline & $(8.92)$ & $(11.93)$ \\
\hline Group firm dummy & $0.0946^{* * *}$ & $-0.2150^{* * *}$ \\
\hline & $(9.39)$ & $(11.66)$ \\
\hline Prob. > F & 0.0000 & 0.0000 \\
\hline
\end{tabular}


Panel B. Trade Credit Equation

\begin{tabular}{|c|c|c|c|c|c|c|}
\hline \multirow[t]{2}{*}{ Dependent variable: } & \multicolumn{3}{|c|}{ Accounts payable/Sales } & \multicolumn{3}{|c|}{ Accounts receivable/Sales } \\
\hline & $\begin{array}{l}\text { Regime } 1 \\
\text { (R1) }\end{array}$ & $\begin{array}{l}\text { Regime } 2 \\
\text { (R2) }\end{array}$ & p-value (R1-R2) & $\left\{\begin{array}{l}\text { Regime } 1 \\
(\mathrm{R} 1)\end{array}\right.$ & $\begin{array}{l}\text { Regime } 2 \\
(\mathrm{R} 2)\end{array}$ & p-value (R1-R2) \\
\hline \multirow[t]{2}{*}{ L1. Dep. Var. } & $0.8375^{* * *}$ & -0.0055 & 0.0000 & $0.1206^{* * * *}$ & $0.6824 * * *$ & 0.0000 \\
\hline & $(13.44)$ & $(0.38)$ & & $(5.57)$ & $(8.71)$ & \\
\hline \multirow[t]{2}{*}{ FGI /Sales } & $0.1035 * * *$ & $0.2326 * * *$ & 0.0000 & $-0.1538 * * *$ & $-0.0413 * * *$ & 0.0000 \\
\hline & $(17.81)$ & $(7.94)$ & & $(4.15)$ & $(9.44)$ & \\
\hline \multirow{2}{*}{ ISFGI /Sales } & $0.0981 * * *$ & $0.3562 * *$ & 0.0000 & $0.1010^{* * *}$ & 0.0079 & 0.0000 \\
\hline & $(19.84)$ & $(14.79)$ & & $(3.67)$ & $(1.79)$ & \\
\hline \multirow[t]{2}{*}{ Log assets } & $0.0027 * * *$ & $0.0128 * * *$ & 0.0007 & $0.0152 * * *$ & $0.0033 * * *$ & 0.0000 \\
\hline & $(5.35)$ & $(4.30)$ & & $(4.58)$ & $(6.56)$ & \\
\hline \multirow[t]{2}{*}{ Collateral } & $-0.0077 * * *$ & $-0.0335 * *$ & 0.0257 & $-0.1671 * * *$ & $-0.0354 * * *$ & 0.0000 \\
\hline & $(4.16)$ & $(2.90)$ & & $(12.41)$ & $(9.44)$ & \\
\hline \multirow[t]{2}{*}{ Profit/Sales } & $-0.0509 * * *$ & $-0.0764 * * *$ & 0.2229 & $-0.0224 * * *$ & -0.0136 & 0.0000 \\
\hline & $(12.61)$ & $(3.66)$ & & $(4.03)$ & $(0.98)$ & \\
\hline \multirow[t]{2}{*}{ Liquid assets/sales } & $0.0207 * * *$ & $0.0767 * * *$ & 0.0017 & 0.0211 & $-0.0081 * *$ & 0.0000 \\
\hline & $(7.86)$ & $(4.30)$ & & $(1.19)$ & $(2.98)$ & \\
\hline \multirow[t]{2}{*}{ STBC/Sales } & $0.0231 * * *$ & $0.0615 * * *$ & 0.0432 & $0.3346 * * *$ & $0.0962 * * *$ & 0.0000 \\
\hline & $(7.19)$ & $(3.24)$ & & $(8.28)$ & $(11.91)$ & \\
\hline Prob. > F & 0.0000 & 0.0000 & & 0.0000 & 0.0000 & \\
\hline
\end{tabular}

Notes: FGI is finished goods inventories. ISFGI is input and semi-finished goods inventory. STBC is short term bank credit. The estimation is done after controlling for firm and year effects. Absolute t-statistics are in parentheses. *,** and $* * *$ represent level of significance at $5 \%, 1 \%$ and $0.1 \%$, respectively

Table 3 reports the estimates of the endogenous regime switching model. To ascertain the existence of two distinct trade credit regimes we conduct a likelihood ratio test as suggested by Goldfeld and Quandt (1976). The test rejects the hypothesis of a single regime at 0.1 percent significance level.

\subsection{Results on Accounts Payable}

In Panel A, the estimates of the selection equation reveal that all the selection characteristics, except liquid assets play important role in determining the likelihood of a firm to be in a particular regime. Specifically, firms which are smaller, mature, pay higher dividend, export more, have lower growth opportunities, have lower credit and are affiliated to a group are more likely to be in the first regime. Most of these characteristics, as discussed above, suggest that the first regime is unconstrained one. With such an interpretation, the coefficient associated with size turns out to be contrary to our expectation. However, it is argued that the directed credit program in India sought to channel more funds to the small scale sectors at the cost of large scale sector, making the later more vulnerable to financing difficulties (Athey 
and Lumas, 1994; Athey and Reeser, 2000; Ganesh-Kumar et al., 2001). The coefficient of growth opportunities, which was ambiguous ex-ante, suggests that financially constrained firms face better growth opportunities than the unconstrained ones.

In Panel B, in both the regimes, the coefficients associated with all the explanatory variables are similar except for the lagged dependent variable. Moreover, except for log assets and liquid assets the coefficients of all other variables are consistent with our expectations (discussed in section 3). Specifically, the coefficient of lagged dependent variable is positive and significant in the first (unconstrained) regime suggesting in favour of persistence. It is insignificant in the second (constrained) regime. Positive and significant coefficients of inventory variables suggest that firms that build up inventories of raw materials and semifinished goods have large accounts payable. Positive and significant coefficient associated with $\log$ assets and liquid assets suggest that reputed (less risky) firms are preferred destination in trade credit transactions. The coefficient associated with collateral and profits turn out to be significant with a negative sign suggesting that firms backed by lower pledgeability and internal funds, respectively, find it difficult to access trade credit. Our main variable of interest, short term bank credit, is although positive and significant in both the regimes; it is significantly greater in the second regime. Since the endogenous regime switching model produces coefficients in relative terms, greater coefficient in the second (constrained) regime suggests that accounts payable and short term bank credit have higher complementarity for financially constrained firms.

\subsection{Results on Accounts Receivable}

In Panel A, the estimates of the selection equation reveal that all the selection characteristics play important role in determining the likelihood of a firm to be in a particular regime. Relying on the characteristics of the regimes in the previous sub-section, we can interpret the first regime as financially constrained.

In Panel B, in both the regimes, the coefficients associated with all the explanatory variables are similar except for input and semi-finished goods inventories, profits and liquid assets. Positive and significant coefficient of the lagged dependent variable suggests persistence in accounts receivable. The coefficient of finished goods inventories is negative and significant suggesting that firms run down such inventories to build up accounts receivable. The coefficient of input and semi-finished goods inventories is positive and significant only in the first (constrained) regime. It implies that constrained firms accumulate stock of input and semifinished goods inventories to balance against receivables. The coefficient associated with $\log$ assets is positive and significant suggesting that firms with larger size are more likely to lend trade credit. Collateral and liquid assets appear with negative and significant coefficients suggesting that firms with lower pledgeability and solvency, respectively, are more likely to offer trade credit. This is justifiable as offering trade credit provides an additional window to hedge against future downside risk. Our main variable of interest, profits, is negative and significant only in the first regime while it is insignificant in the second regime. It suggests that firms which are unconstrained or firms which are constrained and relatively profitable do not offer trade credit. Rather, firms which are constrained and unprofitable do so. 


\section{Robustness Checks}

To check the robustness of our estimates, we conduct two independent exercises. The first exercise pertains to checking the stability of the sensitivity of short term bank credit to accounts payable and sensitivity of profits to accounts receivable for the two groups using the endogenous regime switching model. For this, we use the sub-sample from the year 1993 to 2000 as the base and then add one year in subsequent steps. In the second exercise, we attempt to take care of a potential criticism of the current exercise: the sample consists of listed as well as unlisted firms where the two groups vary to a large extent in terms of informational, financing and other attributes. Moreover, for unlisted firms the proxy for growth opportunities is the accelerator as there is no way to construct Tobin's $q$ for such firms. To take care of these issues, we reiterate the estimation exercise for a sub-sample of firms listed in the Bombay Stock Exchange (BSE).

\subsection{Stability of Sensitivities}

Figure 2 portrays the sensitivity of short term bank credit to accounts payable for the constrained and the unconstrained regimes using the sub-sample from the year 1993 to 2000 as the base and then adding one year in subsequent steps. It can be noticed that across all the sub-samples the sensitivity of short term bank credit to accounts payable is significantly greater in the constrained regime. Thus, our first main result that accounts payable should have higher complementarity with short term bank credit for firms which are financially constrained remains stable. We iterate a similar exercise to check the stability of the sensitivity of profits to accounts receivable which is presented in figure 3 . It can be noticed that across all the sub-samples, except the ones ending with year 2000, to 2002, the sensitivity of profits to accounts receivable is negative and significant in the constrained regime. In contrast, for the unconstrained regime, the sensitivity of profits to accounts receivable is insignificant except for years ending with 2000 and 2001. Thus, our second main result that firms which are unconstrained or firms which are constrained and relatively profitable do not offer trade credit; rather firms which are constrained and unprofitable do so also remains largely stable. 


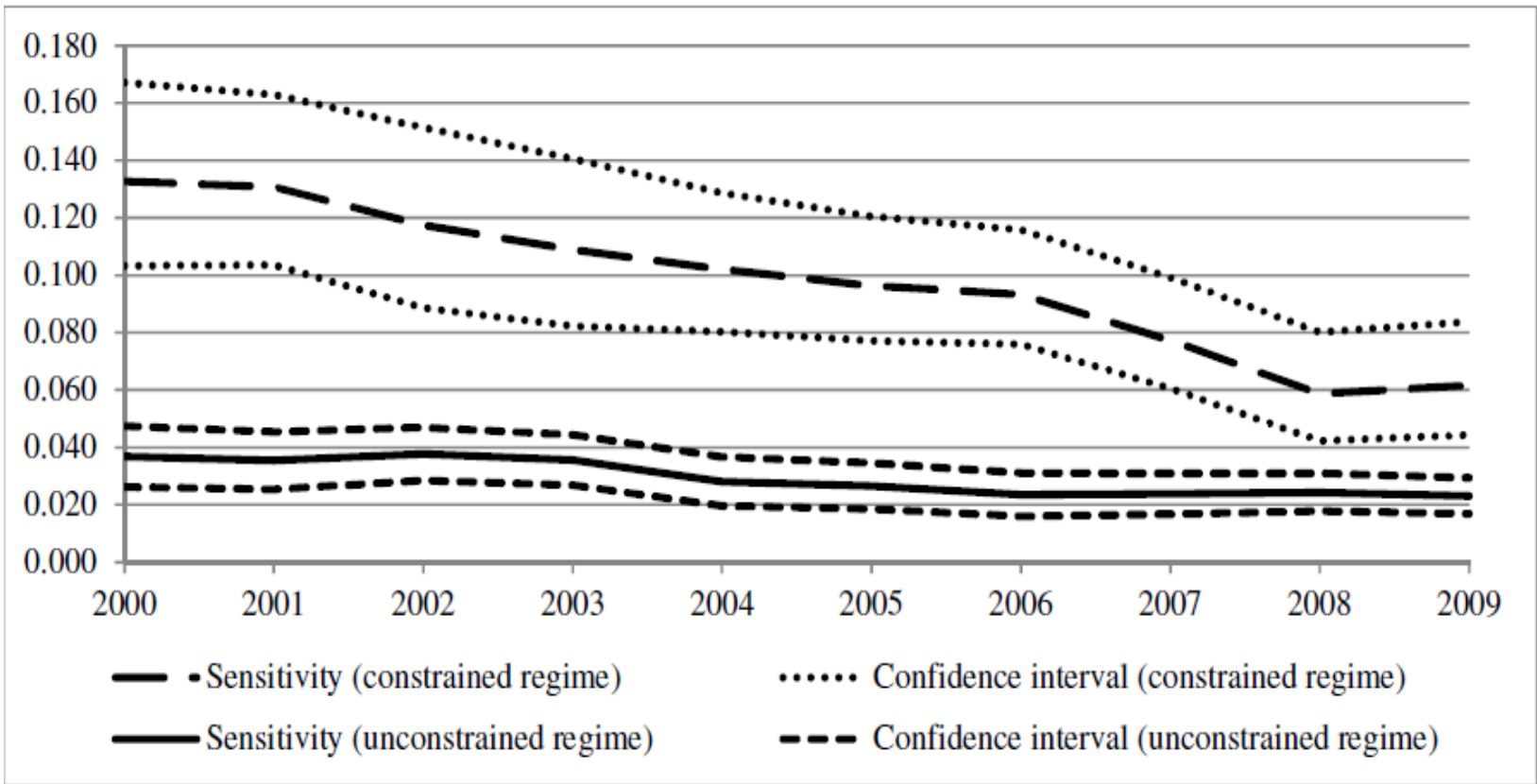

Figure 2. Sensitivity of short term bank credit to accounts payable

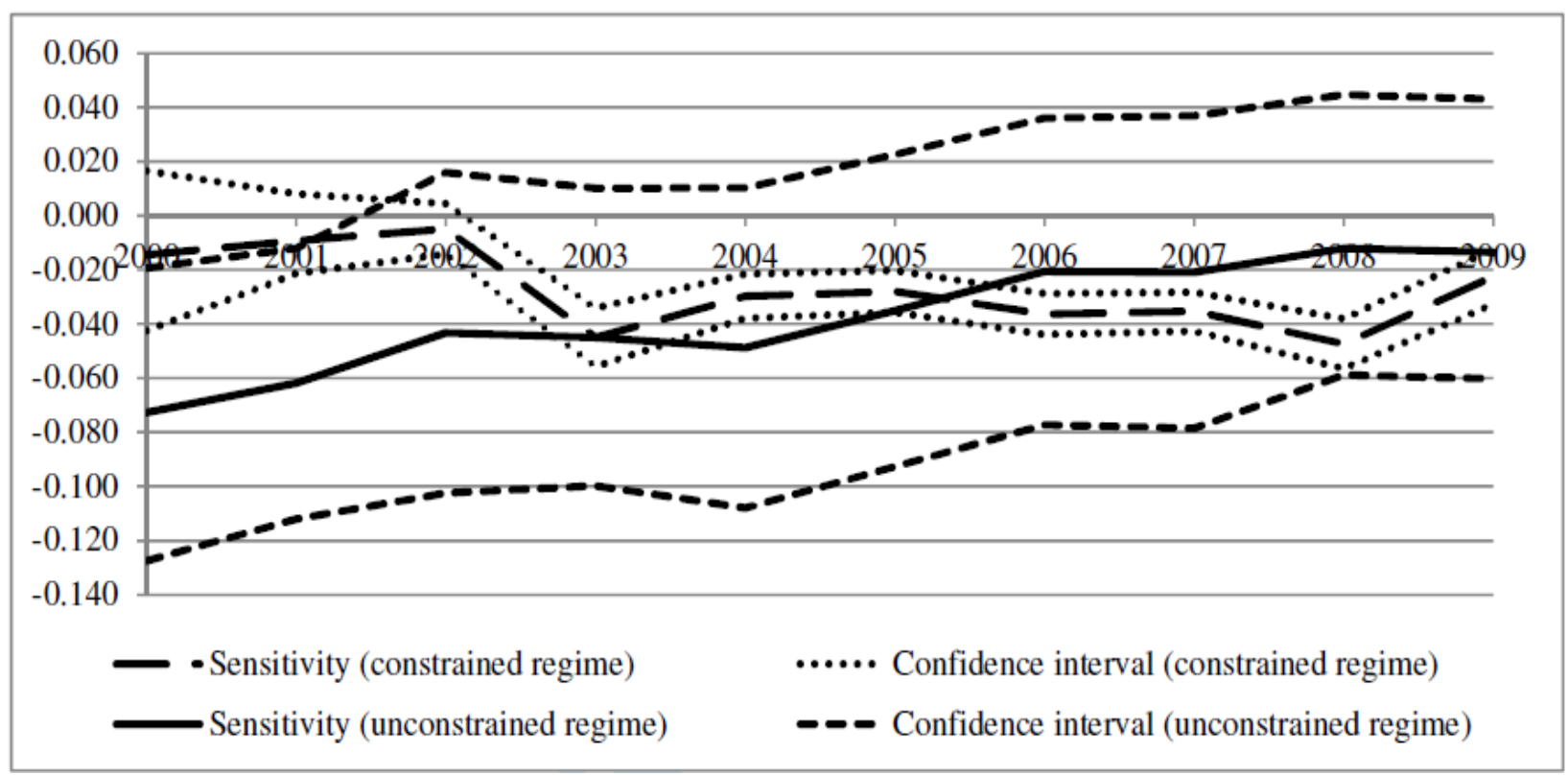

Figure 3. Sensitivity of profits to accounts receivable

\subsection{Estimates for Listed Firms}

Table 4 presents the results of the endogenous regime switching regression for a sub-sample of 746 firms that are listed in the Bombay Stock Exchange. We checked the existence of two distinct trade credit regimes as above. The test rejects the hypothesis of similar trade credit regimes at 0.1 percent significance level.

\subsubsection{Results on Accounts Payable}

In Panel A, the estimates of the selection equation reveal that all the selection characteristics, 


\section{Ml Macrothink}

Business and Economic Research

ISSN 2162-4860

2015, Vol. 5, No. 1

except liquid assets and short term credit, play important role in determining the likelihood of a firm to be in a particular investment regime. Specifically, firms which are larger, young, pay higher dividend, export less, have higher accelerator value, have lower Tobin's $q$, have higher credit and are not affiliated to a group are more likely to be in the first regime. Most of these characteristics suggest that the first regime is the financially constrained one. Although, the coefficients of size and accelerator are counter-intuitive, they remain consistent with table 3. The coefficient of dividend, however, changes sign. Moreover, short term credit, which was significant earlier, turns insignificant. The negative and significant coefficient associated with the additional variable, Tobin's $q$, suggests that listed firms with higher growth opportunities are more likely to be financially unconstrained. In Panel $\mathrm{B}$, in both the regimes, all the significant coefficients are consistent with the estimates in the table 3 . The main variable of interest, short term bank credit, is significantly greater in the first regime suggesting that accounts payable and short term bank credit have higher complementarity for financially constrained firms.

Table 4. Endogenous regime switching model (listed firms)

Panel A. Selection Equation

\begin{tabular}{|l|l|l|}
\hline & Accounts payable/Sales & Accounts receivable/Sales \\
\hline Log assets & $0.2764^{* * *}$ & $0.1136^{* * *}$ \\
\hline & $(9.10)$ & $(8.36)$ \\
\hline Log age & $-0.4455^{* * *}$ & $-0.6451^{* * *}$ \\
\hline & $(8.79)$ & $(9.80)$ \\
\hline Dividend/Sales & $3.7691^{* * *}$ & $-6.9549^{* * *}$ \\
\hline & $(5.09)$ & $(9.52)$ \\
\hline Liquid assets/Sales & -0.1515 & 0.0583 \\
\hline & $(1.96)$ & $(0.76)$ \\
\hline Accelerator/Sales & $0.9580^{* * *}$ & $0.5209^{* * *}$ \\
\hline & $(6.08)$ & $(17.66)$ \\
\hline Tobin's q & $-0.0921^{* * *}$ & $-0.1873^{* * *}$ \\
\hline & $(5.77)$ & $(11.89)$ \\
\hline Short term debt/Sales & -0.0667 & $0.2540^{* * *}$ \\
\hline & $(1.15)$ & $(4.43)$ \\
\hline Long term debt/Sales & $0.5404^{* * *}$ & $0.4420^{* * *}$ \\
\hline & $(7.74)$ & $(7.17)$ \\
\hline Exports/Sales & $-0.6982^{* * *}$ & $-0.2349^{* * *}$ \\
\hline & $(7.73)$ & $(2.63)$ \\
\hline Group firm dummy & $-0.1125^{* * *}$ & $-0.2171^{* * *}$ \\
\hline & $(7.75)$ & $(15.14)$ \\
\hline Prob. > F & 0.0000 & 0.0000 \\
\hline & & \\
\hline
\end{tabular}


Panel B. The Trade Credit Equation

\begin{tabular}{|c|c|c|c|c|c|c|}
\hline & \multicolumn{3}{|c|}{ Accounts payable/Sales } & \multicolumn{3}{|c|}{ Accounts receivable/Sales } \\
\hline & $\begin{array}{l}\text { Regime } 1 \\
\text { (R1) }\end{array}$ & $\begin{array}{l}\text { Regime } 2 \\
\text { (R2) }\end{array}$ & p-value (R1-R2) & $\begin{array}{l}\text { Regime } 1 \\
\text { (R1) }\end{array}$ & $\begin{array}{l}\text { Regime } 2 \\
\text { (R2) }\end{array}$ & $\mathrm{p}$-value (R1-R2) \\
\hline \multirow[t]{2}{*}{ L1. Dep. Var. } & -0.0260 & $0.7902 * * *$ & 0.0000 & 0.0230 & $0.7307 * * *$ & 0.0000 \\
\hline & $(1.32)$ & $(6.97)$ & & $(0.63)$ & $(6.48)$ & \\
\hline \multirow[t]{2}{*}{ FGI /Sales } & 0.0201 & $0.0960 * * *$ & 0.0244 & 0.0146 & -0.0090 & 0.1677 \\
\hline & $(0.29)$ & $(4.92)$ & & $(0.14)$ & $(0.53)$ & \\
\hline \multirow{2}{*}{ ISFGI /Sales } & $0.3058 * * *$ & $0.0999 * * *$ & 0.0014 & $0.1013 *$ & $0.0336 *$ & 0.0000 \\
\hline & $(5.38)$ & (7.94) & & $(2.02)$ & $(2.55)$ & \\
\hline \multirow[t]{2}{*}{ Log assets } & 0.0004 & $0.0043 * *$ & 0.7340 & 0.0074 & $0.0095 * * *$ & 0.1609 \\
\hline & $(0.08)$ & $(2.96)$ & & $(1.29)$ & $(6.50)$ & \\
\hline \multirow[t]{2}{*}{ Collateral } & $-0.1107 * * *$ & -0.0017 & 0.0000 & $-0.1677 * * *$ & $-0.0390 * * *$ & 0.0000 \\
\hline & $(4.37)$ & $(0.34)$ & & $(7.69)$ & $(7.89)$ & \\
\hline \multirow[t]{2}{*}{ Profit/Sales } & 0.0289 & $-0.1024 * * *$ & 0.0849 & $-0.2774 * * *$ & -0.0140 & 0.0000 \\
\hline & $(0.67)$ & $(7.33)$ & & $(6.07)$ & $(1.29)$ & \\
\hline \multirow[t]{2}{*}{ Liquid assets/sales } & 0.0307 & $0.0535 * * *$ & 0.0004 & 0.0185 & -0.0090 & 0.0000 \\
\hline & $(0.85)$ & $(7.02)$ & & $(0.56)$ & $(1.34)$ & \\
\hline \multirow[t]{2}{*}{ STBC/Sales } & $0.1210 * * *$ & $0.0498 * * *$ & 0.0000 & $0.3602 * * *$ & $0.1083 * * *$ & 0.0000 \\
\hline & $(3.55)$ & $(6.04)$ & & $(9.31)$ & $(13.19)$ & \\
\hline Prob. > F & 0.0000 & 0.0000 & & 0.0000 & 0.0000 & \\
\hline
\end{tabular}

Notes: FGI is finished goods inventories. ISFGI is input and semi-finished goods inventory. STBC is short term bank credit. The estimation is done after controlling for firm and year effects. Absolute t-statistics are in parentheses. *,** and $* * *$ represent level of significance at $5 \%, 1 \%$ and $0.1 \%$, respectively

\subsubsection{Results on Accounts Receivable}

In Panel A, the estimates of the selection equation reveal that all the selection characteristics play important role in determining the likelihood of a firm to be in a particular investment regime. Relying on the characteristics of the regimes for accounts payable setup, we can interpret the first regime as financially constrained. Compared to the estimates in table 3 , the coefficients associated with all the variables, except liquid assets, is consistent. Liquid assets, which was significant with a positive sign in the unconstrained regime earlier, turns insignificant. The additional variable, Tobin's $q$, is significant with a negative sign. In Panel $\mathrm{B}$, in both the regimes, all the significant coefficients except input and semi-finished goods inventory are consistent with the estimates in the table 3 . The coefficient associated with input and semi-finished goods turns from insignificant to significant with a positive sign in the second regime. The main variable of interest, profits, is negative and significant only in the first regime while it is insignificant in the second regime. It suggests that firms which are unconstrained or firms which are constrained and relatively profitable do not offer trade credit. Rather, firms which are constrained and unprofitable offer such credit. 


\section{Conclusion}

In this paper we investigate the relationship between trade credit, bank credit and profits when there are imperfections in the credit market. Theory predicts that accounts payable and bank credit should be substitutes for financially unconstrained firms whereas they should be complements for financially constrained firms. Additionally, when rediscounting of accounts receivable is discouraged, firms that are financially unconstrained or firms that are financially constrained but are highly profitable should not invest in accounts payable. Rather, firms that are constrained and relatively unprofitable should do so. The empirical difficulty in ascertaining these relationships is mainly on account of the fact that the finance constraints are not directly observable. We overcome this difficulty by exploiting information from a set of variables using an endogenous regime switching model.

We carry out our empirical exercise for a sample of 3041 private Indian manufacturing firms in the period 1993 to 2009 . We show a greater degree of complementarity between accounts payable and short term bank credit for the financially constrained firms. On the other hand, firms that are financially unconstrained or firms that are financially constrained but are highly profitable are less likely to invest in accounts receivable. Rather, firms that are financially constrained and relatively unprofitable do so. Our robustness checks lend credence to our exercise. Future research may probably consider a focused analysis of an important observation made in the course of analysis. Many firms engage in channeling of short term bank credit to other firms as trade credit. It may have an important macroeconomic implication for the monetary transmission mechanism.

\section{References}

Allen, F., Chakrabarti, R., De, S., Qian, J., \& Qian, M. (2012). Financing firms in India. $\begin{array}{llll}\text { Journal of } & \text { Financial } & \text { Intermediation. } & \text { 21(3). }\end{array}$ http://dx.doi.org/10.1016/j.jfi.2012.01.003

Arellano, M., \& Bond, S. (1991). Some tests of specification for panel data: Monte Carlo evidence and an application to employment equations. Review of Economic Studies. 58(2). 277-297. http://dx.doi.org/10.2307/2297968

Athey, M. \& Laumas, P. (1994). Internal funds and corporate investment in India. Journal of Development Economics. 45(2). 287-303. http://dx.doi.org/ 10.1016/0304-3878(94)90034-5

Athey, M., \& Reeser, W. (2000). Asymmetric information, industrial policy, and corporate investment in India. Oxford Bulletin of Economics and Statistics. 62(2). 267-292. http://dx.doi.org/ 10.1111/1468-0084.00171

Biais, B. \& Gollier, C. (1997). Trade credit and credit rationing. Review of Financial Studies. 10(4). 903-937. http://dx.doi.org/ 10.1093/rfs/10.4.903

Blundell, R., \& Bond, S. (1998). Initial conditions and moment restrictions in dynamic panel data models. Journal of Econometrics. 87(1). 115-143. http://dx.doi.org/ 10.1016/S0304-4076(98)00009-8 
Bougheas, S., Mateut, S., \& Mizen, P. (2009). Corporate trade credit and inventories: New evidence of a trade-off from accounts payable and receivable. Journal of Banking and Finance. 33(2). 300-307. http://dx.doi.org/ 10.1016/j.jbankfin.2008.07.019

Burkart, M., \& Ellingsen, T. (2004). In-kind finance: A theory of trade credit. American Economic Review. 94(3). 569-590. http://dx.doi.org/ 10.1257/0002828041464579

Cunat, V. (2007). Trade credit suppliers as debt collectors and insurance providers. Review of Financial Studies. 20(2). 491-527. http://dx.doi.org/ 10.1093/rfs/hhl015

Devereux, M., \& Schiantarelli, F. (1990). Investment, financial factors, and cash flow: Evidence from UK panel data. In G. Hubbard, (Eds.), Asymmetric information, corporate finance, and investment (pp. 279-306), National Bureau of Economic Research.

Fazzari, S., \& Petersen, B. (1993). Working capital and fixed investment: New evidence on financing constraints. Rand Journal of Economics. 24(3), 328-341. http://dx.doi.org/ $10.2307 / 2555961$

Fazzari, S., Hubbard, R., \& Petersen, B. (1988). Financing constraints and corporate investment. Brookings Papers on Economic Activity. 141-195. http://dx.doi.org/10.2307/2534426

Ganesh-Kumar, A., Sen, K. \& Vaidya, R. (2001). Outward orientation, investment and finance constraints: A study of Indian firms. Journal of Development Studies. 37(4). 133-149. http://dx.doi.org/10.1080/00220380412331322071

Gilchrist, S. \& Himmelberg, C. (1995). Evidence on the role of cash flow for investment. Journal of Monetary Economics. 36(3), 541-572. http://dx.doi.org/10.1016/0304-3932(95)01223-0

Goldfeld, S., \& Quandt, R. (1976). Techniques for estimating switching regressions. In S. Goldfeld \& R. Quandt (Eds.), Studies in non-linear estimation. Cambridge: Ballinger Press.

Hoshi, T., Kashyap, A., \& Scharfstein, D. (1991). Corporate structure, liquidity, and investment: Evidence from Japanese industrial groups. Quarterly Journal of Economics. 106(1). 33-60. http://dx.doi.org/10.2307/2937905

Hovakimian, G., \& Titman, S. (2006). Corporate investment with financial constraint: Sensitivity of investment to funds from voluntary asset sales. Journal of Money, Credit and Banking. 38(2). 357-374. http://dx.doi.org/10.1353/mcb.2006.0034

Hu, X., \& Schiantarelli, F. (1998). Investment and capital market imperfections: A switching regression approach using US firm panel data. Review of Economics and Statistics. 80(3). 466-479. http://dx.doi.org/10.1162/003465398557564

Jensen, M., \& Meckling, W. (1976). Theory of the firm: Managerial behavior, agency costs, and ownership structure. Journal of Financial Economics. 3(4). 305-360. http://dx.doi.org/10.1016/0304-405X(76)90026-X

Kaplan, S., \& Zingales, L. (1997). Do investment-cash flow sensitivities provide useful 


\section{Macrothink}

Business and Economic Research ISSN 2162-4860 2015, Vol. 5, No. 1

measures of financing constraints? Quarterly Journal of Economics. 112(1). 169-215. http://dx.doi.org/10.1162/003355397555163

Miwa, Y., \& Ramseyer, J. (2005). Trade credit, bank loans, and monitoring: Evidence from Japan. Discussion Paper No. 527. John M. Olin Center for Law, Economics, and Business. Harvard Law School.

Nickell, S. (1981). Biases in dynamic models with fixed effects. Econometrica. 49(6). 1417-1426. http://dx.doi.org/ 10.2307/1911408

Petersen, M., \& Rajan, R. (1997). Trade credit: Theories and evidence. Review of Financial Studies. 10(3). 661-691. http://dx.doi.org/ 10.1093/rfs/10.3.661

Whited, T., \& Wu, G. (2006). Financial constraints risk. Review of Financial Studies. 19(2). 531-559. http://dx.doi.org/ 10.1093/rfs/hhj012

Wilner, B. (2000). The exploitation of relationships in financial distress: The case of trade credit. Journal of Finance. 55(1). 153-178. http://dx.doi.org/ 10.1111/0022-1082.00203

\section{Appendix: Definition of Variables in the Selection Equation}

Accelerator: First difference of operating income (sales).

Liquid assets: Sum of marketable securities, cash balances and bank balances.

Dividend: Sum of common and preference dividends.

Exports: Ratio of export of goods (fob) to sales.

Group firm dummy: It takes the value 1 for a firm belonging to group.

Long term credit: Credit from all sources for a period exceeding 12 months.

Log age: Natural log of age where age is the difference between year of incorporation to the current year.

Log assets: Natural log of total assets.

Regime dummy: It takes the value 1 for the first regime.

Short term credit: Credits taken from all sources for a period of less than 12 months.

Tobin's q: The ratio of market value of a firm to its book value of assets. Market value is calculated by adding market value of equity and book value of debt. Market value of equity is number of outstanding shares and share price on the closing day of the year.

\section{Copyright Disclaimer}

Copyright for this article is retained by the author(s), with first publication rights granted to the journal.

This is an open-access article distributed under the terms and conditions of the Creative Commons Attribution license (http://creativecommons.org/licenses/by/3.0/). 